\title{
Effectiveness of Monitoring and Evaluation of Online Learning in Accounting Study Program for Continuous Improvement
}

\author{
Mariana $^{1, *}$ Ambar Kusumaningsih ${ }^{1}$ Merlyana D. Yanthi ${ }^{1}$ \\ Rohmawati Kusumaningtias ${ }^{1}$
}

\author{
${ }^{1}$ Universitas Negeri Surabaya \\ *Corresponding author. Email: mariana@unesa.ac.id
}

\begin{abstract}
The Covid-19 pandemic is still happening in the world. However, learning activities must continue. One solution from the government is to implement a policy of learning from home or online learning. Even though learning is online, educational institutions are still trying to meet learning objectives, so monitoring and evaluating online learning is essential. This study aims to determine the effectiveness of online learning monitoring and evaluation in the Accounting Study Program Faculty of Economics and Business Universitas Negeri Surabaya. The research method is quantitative with a descriptive approach. The sampling method was purposive sampling with respondents as many as 358 students in charge of subjects in the Bachelor Accounting study program Faculty Economics and Business Universitas Negeri Surabaya. Data collection was carried out using a google form survey. The study results indicate that implementing online learning monitoring and evaluation in the Accounting Study Program Faculty Economics and Business Universitas Negeri Surabaya is still less effective. This is indicated by the overall level of student participation who fills in the new monitoring link of $39.08 \%$ of all respondents. Students still need to be activated to fill in the lecture monitoring link so that the results can be used as material for evaluating the learning process. The learning process must be evaluated for continuous improvement and ensure that online learning can still achieve the expected learning objectives.
\end{abstract}

Keywords: Online learning, Monitoring and evaluation, Continuous improvement, Bachelor accounting study program.

\section{INTRODUCTION}

In the middle of 2021, the Covid-19 pandemic is still happening in the world. The Covid-19 pandemic has changed the pattern of learning from face-to-face to a distance or online learning system. The online learning process has been carried out for three semesters, to be precise, starting in March 2020. The educational process carried out at universities currently refers to the Joint Decree of the Four Ministers to prevent campuses from becoming new clusters of the spread of Covid-19 and to maintain the health and safety of students, educators, education staff, families, and the community while still fulfilling student learning rights until the end of the semester or until there is the further direction from the task force for the acceleration of handling Covid-19. Education is the primary sector in the development of the Indonesian nation. Quality human resources strongly support quality dev elopment. Education is the key to the growth and development of quality human resources that are intact. Based on Presidential Decree number 11 of 2020 concerning the Determination of the COVID-19 public health emergency in Indonesia, which the provisions of laws and regulations must carry out, the Directorate General of Higher Education carried out various strategies to carry out these efforts. In order to avoid the transmission and spread of the COVID-19 pandemic, policies have been issued to work, worship, and study from home; face-to-face learning has been changed to online learning. The implementation of online learning encourages all parties to play an active role starting from students, lecturers, education staff, and quality assurance referring to the Joint Decree of the Four Ministers Number 01/KB/2020 dated June 15, 
2020, regarding Guidelines for the Implementation of Learning in the 2020/2021 Academic Year and the 2020/2021 Academic Year in the Corona Virus Disease (Covid-19) Pandemic Period that the learning method in higher education in all zones must be carried out online for theoretical courses and wherever possible also for practical courses.

The Ministry of Education and Culture (Kemendikbud) has evaluated the implementation of online learning since March 2020. The survey was conducted on eight million students and 300,000 lecturers. Based on the survey results, 70 per cent stated that online learning was considered good or even very good, another 30 per cent admitted that there were still weaknesses. Constraints such as affordability and network stability, sometimes the sound is lost in the middle of a lecture or disconnection [14]. Previous research states that students' biggest problems during online learning are internet connections [13]. Meanwhile, quality is a dynamic state associated with products, services, people, processes, and environments that meet or exceed expectations and help generate excellence [3]. So maintaining the quality of education during this pandemic and online learning is very important, one of which is monitoring and evaluating.

The online learning system in an emergency during a pandemic is not as effective as a face-to-face system. Many things need to be adequately prepared so that the learning process can run optimally. For example, infrastructure such as a good internet network. In addition to infrastructure in networks and online platforms, namely the readiness of human resources (HR) for both students and educators. Hence, there is a need for monitoring and evaluation in the online learning process to ensure that the learning process is as expected.

The implementation of quality assurance in higher education concerning the higher education quality assurance system (SPM Dikti) [6] and National Higher Education Standards [7]. SPMI (Internal Quality Assurance System) is planned, implemented, evaluated, controlled, and developed by universities [6]. Referring to the above, regulations, monitoring and evaluation activities in the online learning process must be carried out by universities. In this case, the smallest unit is in the study program. Monitoring and evaluation are necessary to maintain the quality of learning in the S1 Accounting Study Program, Faculty of Economics and Business, Universitas Negeri Surabaya. So this study aims to determine the effectiveness of online learning monitoring and evaluation in the Accounting Study Program FEB UNESA.

\section{LITERATURE REVIEW}

\subsection{Online Learning}

According to the Law of the Republic of Indonesia Number 20 of 2003 concerning the National Education System, that learning is a process of interaction between educators and students and learning resources that take place in a learning environment. Online learning means learning that is done online, using learning applications and social networks [5]. Online learning is learning that is done without face-to-face but through an available platform. All subject matter forms are distributed online, communication is also carried out online, and tests are also carried out online. Several applications, such as vi, assist this online learning system- learn, Google Classroom, Google Meet, Edmodo and Zoom. There is also an internet-based interactive model and a Learning Management System (LMS).

\subsection{Internal Quality Assurance System (SPMI)}

The quality assurance system in universities is carried out internally by the universities concerned through the implementation of the Internal Quality Assurance System (SPMI) and externally carried out by BAN-PT and LAM PTKES through the External Quality Assurance System (SPME).

Based on Permendikbud No. The higher education quality assurance system is a systemic activity to improve the quality of higher education in a planned and sustainable manner. 50 of 2014 Article 1, the quality of higher education is the level of conformity between the implementation of higher education and higher education standards consisting of national higher education standards and higher education standards set by universities. The internal quality assurance system, abbreviated as SPMI, is a systemic activity of quality assurance of higher education by each tertiary institution autonomously to control and improve the implementation of higher education in a planned and sustainable manner.

The Internal Quality Assurance System at Unesa follows the regulations based on the applicable laws. Quality Assurance System Policy at Univ. The State of Surabaya is based on the rector's regulation regarding the implementation of SPMI at Unesa. Determination of quality policies and documents consisting of quality policies, quality manuals, quality standards and quality forms are used to establish, implement, evaluate, control and improve the quality standards of PT and Study Program Management Units. Universities' efforts in carrying out SPMI at UNESA are based on PPEPP.

1. Determination (P). Quality policy and document setting activities, Academic Senate at Unesa to establish policies and quality documents. Every 
year the standards are revised and developed by considering and controlled based on evaluation by being audited by the Quality Assurance Division at the PT.

2. Implementation (P). All leaders carry out activities for implementing quality policies and documents at the PT, Faculties and Study Program levels as well as the supervisors of activities in education, research, service, and other supports such as supporting standards for the tri dharma (Students, Alumni, Curriculum, Libraries, Vision, Mission, Administration, PT Outcomes, Information Technology, product specifications).

3. Evaluation (E). Quality Assurance carries out evaluation activities by conducting audits 1) online through a system called SSO-SIMPPM by filling out and uploading data tables and document evidence and 2) offline through observation and interviews using instruments from the standards to be evaluated. The results of this evaluation will be summarized through an evaluation report based on the implementation of standards and an assessment of the success or lack of standards. The report will be made by the Quality Assurance Center and given to the leadership.

4. Control (P). Control activities are carried out by reviewing the results of the joint evaluation of the audit results and the improvement program of the Management Review Meeting (RTM). This control will formulate businesses that need to be improved and solve the problem long or short term.

5. Increase $(\mathrm{P})$. Improvement activities are carried out by making work programs annual to repair the identified deficiencies and maintain or improve the results that have been declared successful.

\subsection{Independence and Discipline}

Independence cannot be completed in one stage of life but will continue to develop in every stage of individual development. Independence begins at the age of children, adolescents, and early adulthood. In Piaget's theory of cognitive development, adolescents are in the formal operational stage, which is well-acquired between 15 and 20 years. He can distinguish and discuss abstract things, such as love, justice, and freedom. Teenagers' thinking abilities become more abstract, idealistic, and logical. Increased ability in abstract thinking makes them able to see other people's perspectives, reason better, and see the consequences of each alternative action to weigh other people's opinions and suggestions more effectively and make their own decisions.

Currently, most individuals leave their homes and face the outside world on their terms. They also have more roles and activities than in previous times. They study at a higher level, study outside the city, work, or build their home life. In young adulthood, the individual tries to establish himself in the adult world.

These roles and activities inevitably require him to act and decide something based on his value considerations, or in other words, to become an independent person. A student as a young adult is when a person must be responsible for his actions and decisions. Students are a period where there is an increase in the demands of independence in themselves.

Three things will determine the effectiveness of distance learning. First, technology; students should have easy access to the network with minimal time. Second, the characteristics of the teacher. Teachers play an essential role in the effectiveness of online learning. Third, the characteristics of the students themselves. The effectiveness of online learning can be optimized with a high level of discipline - both from lecturers and students sides. Students with high independence and discipline will be able to follow online learning well.

\section{METHODS}

The research approach used is quantitative, and the type of research used is descriptive research. The quantitative approach is a research method based on the philosophy of positivism and is used to examine specific populations or samples; the data collection uses research instruments, data analysis is quantitative or statistical, intending to test pre-defined hypotheses [10]. Descriptive research is research conducted to determine the value of independent variables, either one or more (independent) variables, without making comparisons or connecting one variable to another.

The variable of this research is the effectiveness of monitoring and evaluation of online learning, and the form of the variable is single. Single variable means not looking for the influence or relationship of other variables but intends to describe the effectiveness of monitoring and evaluating learning from the $\mathrm{S} 1$ Accounting Study Program FEB UNESA. The research design is a quantitative descriptive study to provide an overview of facts or events regarding the characteristics of the population or sample.

The method of data collection was carried out using a survey method via a google form link. Furthermore, the research begins with making instruments (questions), collecting data, analyzing data and drawing conclusions. The instruments used are open questions and closed questions. In closed questions, respondents are directed to choose the answers that have been provided by the researcher, while in open questions, respondents are given the freedom to determine their answers. Through open-ended questions, it is hoped that various answers can be obtained. 
The operational definition of the variables in this study is the effectiveness of online learning monitoring and evaluation in the Accounting Study Program FEB Unesa with the following indicators:

1. Lectures according to the schedule are the achievements of lectures carried out according to the schedule set by the Study Program.

2. Lecture material according to the syllabi is the achievement of the material described by the Lecturer following the syllabi that all Lecturers of Subjects have determined.

3. A conducive lecture atmosphere is an achievement of a supportive atmosphere in the Teaching and Learning Process (PBM).

4. According to the syllabi, the lecture method is used in lectures following the syllabi that all course lecturers have determined.

5. Lecturer communication quality is the achievement of good Lecturer communication quality in each PBM per meeting.

6. Instructions related to tasks/questions are clear and easy to understand, which is the achievement of instructions related to tasks/questions from Lecturers that are clear and easy to understand.

The data collection technique is an activity carried out by researchers to obtain data used in research. The data collection technique used in this study used an online learning questionnaire in a google form (questionnaire) distributed to students. The research population, namely all students of the Accounting Department, Faculty of Economics and Business, Unesa in the Odd and Even Semesters 2020- 2021 who participated in online learning, can be seen in Table 1.

Table 1. Research population

\begin{tabular}{|l|l|l|}
\hline Level & ¿College Student & Population \\
\hline 2017 & 60 & 840 \\
\hline 2018 & 82 & 1148 \\
\hline 2019 & 114 & 1596 \\
\hline 2020 & 118 & 1652 \\
\hline Total & 374 & 5236 \\
\hline
\end{tabular}

The research sample used purposive sampling with several criteria, namely that the respondent oversaw the course at each meeting and attended online lectures in the Odd and Even Semesters of 2020-2021. The person in charge of the course is a student who oversees a particular course as agreed in the class. The research sample uses the Slovin formula:

$$
n=\frac{N}{N(e)^{2}+1}
$$

The value of the degree of accuracy or margin of error in this study is 5\%, and the confidence level is $95 \%$. So, it can be seen that the research sample is 358 respondents.

\section{RESULTS AND DISCUSSION}

\subsection{Preparation of Online Learning Monitoring and Evaluation Media}

One media used to monitor and evaluate online learning in the Accounting Study Program FEB UNESA is to use the Google Form platform. The reason for using the platform is the ease of access, use, and features that are suitable for monitoring and evaluation needs. The initial step taken was to create a question instrument consisting of a group of questions (1) class identity, (2) closed questions related to learning monitoring and evaluation, and (3) open questions related to learning monitoring and evaluation. The number of question instruments is 17 questions with the following details:

a. Group 1: class Identity $=6$ questions

b. Group 2: closed questions $=6$ questions

c. Group 3: open questions $=5$ questions

The next step is setting up the questionnaire on the Google Form platform using the Accountancy Department FEB UNESA account connected to the Google domain. The questionnaire as a learning monitoring and evaluation medium was then tested by the Quality Assurance Unit (UPM) Team of the Accounting Department FEB UNESA as a quality assurance step before the questionnaire links were distributed to students to be filled out.

Table 2. Number of monitoring and evaluation objects

\begin{tabular}{|l|l|l|l|l|}
\hline N & Semeste & $\begin{array}{l}\text { Number } \\
\text { of } \\
\text { Classes }\end{array}$ & $\begin{array}{l}\text { Number } \\
\text { of } \\
\text { Meetings }\end{array}$ & $\begin{array}{l}\text { Number of } \\
\text { Monitoring } \\
\text { and } \\
\text { Evaluations } \\
\text { Objects }\end{array}$ \\
\hline 1 & Odd & 61 & 14 & 854 \\
\hline 2 & Even & 45 & 14 & 630 \\
\hline & & Total & & 1484 \\
\hline
\end{tabular}




\subsection{Online Learning Monitoring and Evaluation Data Collection}

Data was collected by distributing questionnaire links to students. The target respondent is the person in charge of the course, namely the student in charge of the particular subject agreed upon in the class and batch taking the course. Each person in charge of the course is asked to fill out a monitoring and evaluation questionnaire for online learning at the end of each meeting in the related subject. Considering the number of courses and meetings taken during the observation period, namely the Odd and Even Semesters 2020/2021, the population of monitoring and evaluating online learning is presented in Table 2.

As with other questionnaires, not all target respondents filled out in the data collection process, so the response rate obtained was less than $100 \%$. The details of the level of student participation in the data collection process in the Odd and Even semesters 2020/2021 are presented in Table 3

Table 3. Number of Monitoring and Evaluation Objects

\begin{tabular}{|c|c|c|c|c|}
\hline $\begin{array}{l}\mathrm{N} \\
\mathrm{O}\end{array}$ & $\begin{array}{l}\text { Semeste } \\
\text { rs }\end{array}$ & $\begin{array}{l}\text { Number } \\
\text { of } \\
\text { Monitori } \\
\text { ng and } \\
\text { Evaluatio } \\
\text { ns } \\
\text { Objects }\end{array}$ & $\begin{array}{l}\text { Number } \\
\text { of } \\
\text { Respons } \\
\text { es } \\
\text { Received }\end{array}$ & $\begin{array}{l}\text { Response } \\
\text { Rate }\end{array}$ \\
\hline 1 & Odd & 854 & 339 & $39,70 \%$ \\
\hline 2 & Even & 630 & 241 & $38,25 \%$ \\
\hline & Total & 1484 & 580 & $39,08 \%$ \\
\hline
\end{tabular}

\subsection{Results of Monitoring and Evaluation of Online Learning}

The data that has been collected is then processed to obtain conclusions from the results of monitoring and evaluation of online learning. From the 3 (three) groups of questions above, different data processing systems were carried out. For question group 1 (Class Identity), the processing is carried out to determine which classes and classes are actively participating in the monitoring and evaluation process. For question group 2 (Closed Questions), data processing was carried out according to the responses obtained from students and used to conclude. Moreover, in question group 3 (Open Questions), the answers were categorized to formulate conclusions. The following are the details of the results of online learning monitoring and evaluation in the Accounting Study Program FEB UNESA for 2020/2021 Odd and Even Semesters.:

\subsubsection{Students Participation Rate}

Following Table 2 above, it is known that the overall student participation rate is $39.08 \%$. Based on the processing of questionnaire data in question group 1 (Class Identity), it is known that the 3 (three) classes with the most significant participation are 2020 A (24\%), 2020 B (20\%) and 2020 I (20\%). Meanwhile, the class with the lowest participation is $2017 \mathrm{~A}(0.69 \%)$ and $2017 \mathrm{~B}(0.17 \%)$. This shows that the most significant number of respondents is from the class of 2020who are still new students with the most significant number of classes compared to the batches of 2019, 2018 and 2017. Further observations show that student participation in the class of 2018 varies quite a lot, which is between $4.32 \%$ (2018 B) with $10.88 \%$ (2018 A) even though both classes take the same number of classes. Meanwhile, for the class of 2019 students, the participation rate is relatively the same, which is between $5.01 \%$ to $7.43 \%$.

The low level of student participation in general, especially in the senior class (2018 and 2017), indicates the need for evaluation related to the monitoring and evaluation methods carried out. It is necessary to reexamine the causes of the low level of participation, whether in terms of the lack of socialization from the Quality Assurance Unit Team and Lecturers, the lack of student awareness of the importance of monitoring and evaluation, or a large number of administrative burdens in charge of the course so that they do not have time or forget to fill out the available monitoring and evaluation questionnaires. Another aspect that may cause is the absence of a reward and punishment system related to student participation and media that have not been integrated with the online learning system at UNESA, namely Vilearning and SIAKADU.

\subsubsection{Learning Monitoring}

In question group 2 (Closed Questions), there are six indicators used to measure the effectiveness of online learning. The results obtained in each semester are as presented in Table 4.

Based on the results of the questionnaire presented in table 4 above, compared to the Odd Semester period results with the Even Semester 2020/2021, in general, there is a decrease in the quality of online learning on all indicators asked students. Although in general, students have assessed the effectiveness of online learning as more than $85 \%$, the decline in scores in the Even Semester 2020/2021 period gave rise to new indications, namely a decrease in the quality of online learning and 
that the media used for monitoring and evaluation was not optimal.

Table 4. Results of monitoring and evaluation of online learning

\begin{tabular}{|c|c|c|c|}
\hline N & Indicator & $\begin{array}{l}\text { Odd } \\
\text { Semester } \\
2020 / 2021\end{array}$ & $\begin{array}{l}\text { Even } \\
\text { Semester } \\
2020 / 2021\end{array}$ \\
\hline 1 & $\begin{array}{l}\text { Classes according } \\
\text { to schedule }\end{array}$ & $90,27 \%$ & $85,06 \%$ \\
\hline 2 & $\begin{array}{l}\text { Lecture material } \\
\text { according to RPS }\end{array}$ & $99,71 \%$ & $98,76 \%$ \\
\hline 3 & $\begin{array}{l}\text { Conducive learning } \\
\text { atmosphere }\end{array}$ & $99,12 \%$ & $98,34 \%$ \\
\hline 4 & $\begin{array}{l}\text { Lecture method } \\
\text { according to RPS }\end{array}$ & $99,71 \%$ & $98,76 \%$ \\
\hline 5 & $\begin{array}{l}\text { Lecture method } \\
\text { according to RPS }\end{array}$ & $99,71 \%$ & $97,51 \%$ \\
\hline 6 & $\begin{array}{l}\text { Instructions related } \\
\text { to } \\
\text { assignments/questi } \\
\text { ons are clear and } \\
\text { easy to understand }\end{array}$ & $98,82 \%$ & $97,51 \%$ \\
\hline
\end{tabular}

\subsubsection{Obstacles Encountered}

The results of data processing for question group 3 (Open Questions) show that there are 6 (six) categories of obstacles that arise in the online learning process in the Odd and Even Semesters of 2020/2021. Details of the results of data processing are presented in Table 5 .

Based on the data presented in Table 5 above, network constraints are the most dominant obstacle to online learning. This is consistent with previous research that stated that students' most problems during online learning were internet connections [13]. The position of students when participating in learning is spread out in various areas with different internet network qualities; there are even areas that have not been reached by a stable internet signal so that students have to carry out the learning process in other areas.

The next obstacle is related to the lecture media used and the limited internet quota. The monitoring results show that the media used is the UNESA online class platform, namely Vilearning, and the general platform, namely Google Classroom, Whatsapp Group, Zoom, and Google Meeting. Use of online media has started to be used by a small number of UNESA lecturers before the pandemic period and has only been fully used during the pandemic. This causes a culture shock, where students feel they are not familiar with the media used and have difficulty participating in learning with online media. This obstacle is also consistent with previous research, which states that some of the online media used are considered to require too much internet quota, students are not familiar with online media, and the media used is considered complicated or heavy [13]. Although there are several obstacles, there are improvements in the Even Semester 2020/2021, namely in lecture media and the quality of communication or interaction between Lecturers and Students. Things that need attention are the increasing constraints on class schedules and student complaints regarding lecturers who are difficult to contact.

Table 5. Constraints faced by students

\begin{tabular}{|l|l|l|l|}
\hline N & Indicator & $\begin{array}{l}\text { Odd } \\
\text { Semester } \\
2020 / 2021\end{array}$ & $\begin{array}{l}\text { Even } \\
\text { Semester } \\
2020 / 2021\end{array}$ \\
\hline 1 & No constraint & $55,46 \%$ & $58,5 \%$ \\
\hline 2 & Network constraint & $24,19 \%$ & $26,6 \%$ \\
\hline 3 & $\begin{array}{l}\text { Less than optimal } \\
\text { lecture media }\end{array}$ & $\begin{array}{l}\text { Quality } \\
\text { communication }\end{array}$ & $2,1 \%$ \\
\hline 5 & $\begin{array}{l}\text { Lectures are not } \\
\text { according to } \\
\text { schedule }\end{array}$ & $\begin{array}{l}2,95 \% \\
\text { Lectures are } \\
\text { difficult to contact }\end{array}$ & $2,69 \%$ \\
\hline 6
\end{tabular}

\section{CONCLUSION}

Based on the discussion results above, the implementation of online learning monitoring and evaluation carried out in the Accounting Study Program FEB UNESA is still less effective. This is indicated by the overall level of student participation who fills the new monitoring link of $39.08 \%$ of the total respondents. However, with participation that is still low, the overall implementation of online learning in the Accounting Study Program during the odd and even semesters of the $2020 / 2021$ academic year can provide satisfaction to students. This can be seen in the delivery of material from lecturers to students, which students can receive both in terms of time, media used, delivery, and communication with lecturers. As an evaluation material for the next academic year, namely increasing student 
participation in filling out the google form link in a disciplined and independent manner. The independence and discipline of all parties are the keys to the success of online learning.

For quality assurance, it is necessary to consistently improve good communication to the person in charge of the courses in each class so that after lectures, complete the evaluation and monitoring link for online lectures. The inputs and obstacles during online learning can improve study program managers to establish good communication with lecturers and students.

\section{REFERENCES}

[1] Z. Aminudin, M. R. D. R. Raymundo, and K. Mir, "Implementing quality assurance system for open and distance learning in three Asian open universities: Philippines, Indonesia and Pakistan", 2020.

[2] T. Belawati., and Nizam, Portrait of Higher Education in the Time of Covid-19. Directorate General of Higher Education, Ministry of Education and Culture, 2020.

[3] D. L. Goetsch, and S. Davis, Quality Management: Introduction to Total Quality Management for Production (Pearson Ne), Edinburgh: Pearson, 2014.

[4] Hamalik, Teaching and learning process, Jakarta : Bumi Aksara, 2001.

[5] T. Ivanova., N. Gubanova., I. Shakirova., and F. Masitoh, "Educational technology as one of the terms for enhancing public speaking skills," Universidad y Sociedad, vol.12, no.2, pp. 154- 159, 2020

[6] Permenristekdikti no. 62 of 2016 about the higher education quality assurance system (SPM Dikti), Jakarta, 2016.

[7] Permendikbud no. 3 of 2020 concerning the national standards of higher education, Jakarta, 2020.

[8] N. Putra, Educational Qualitative Research Methods, Rajawali Pers, 2013.

[9] Quality Standards of the Surabaya State University Undergraduate Education Program. Quality Assurance Center 2019, Surabaya, 2019.

[10] Sugiyono, Quantitative, Qualitative, and $R \& D$ Research Methods, Bandung : Alfabeta, 2017.

[11] Circular Letter of the Ministry of Education and Culture Number 4 of 2020 concerning Implementation of Education in Period Covid-19 Emergency, 2020.
[12] A.S Syarifudin, "Implementation of Online Learning to Improve the Quality of Education as an Impact of the Implementation of Social Distancing," Journal of Language and Literature Education, 2020.

[13] A. Widodo and Nursaptini, "Problems of Online Learning in Student Perspective," Elementary School Education Journal, 2020.

[14] https://itjen.kemdikbud.go.id/ accessed Monday, July 5, 2021 at 15.33 